\title{
Employer branding and employee value proposition: The key success of startup companies in attracting potential employee candidates
}

\author{
Rizqi Ariyanto ${ }^{1}$, Kustini Kustini2 ${ }^{*}$ \\ Department of Management Economics, Faculty of Economics and Business, UPN "Veteran" Jawa \\ Timur, Surabaya, Indonesia ${ }^{1,2}$ \\ rizqi.ariyantos.1739@gmail.com ${ }^{1}$, kustini.ma@upnjatim.ac.id ${ }^{2}$
}

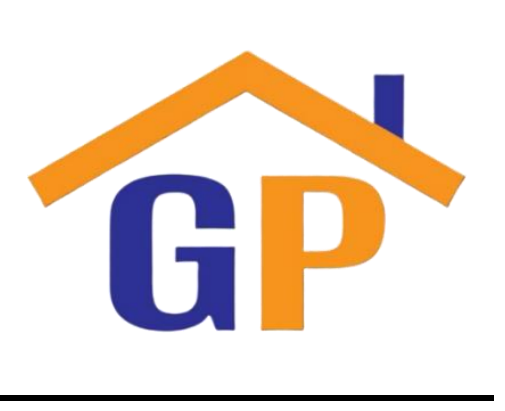

Article History

Received on 26 July 2021

$1^{\text {st }}$ Revision on 28 August 2021

$2^{\text {nd }}$ Revision on 24 September 2021

Accepted on 29 September 2021

\begin{abstract}
Purpose: This study aims to analyze employer branding and employee value proposition on employer attractiveness in potential employee candidates of Startup Campuspedia Indonesia.

Research methodology: This study uses quantitative research methods that are processed using Smart PLS software. The sampling technique used is proportional random sampling with a total of 51 samples.
\end{abstract}

Results: The results show that employer branding and employee value proposition have a positive and significant impact on employer attractiveness at Startup Campuspedia Indonesia.

Limitations: The limitation of this study is that it only uses one startup company in the field of education as the object of research and has not used several companies with different backgrounds.

Contribution: The results of this study can be useful for Human Capital in the company's recruitment process in the next period as an effort to increase the interest of prospective employees to work in the company.

Keywords: Employer branding, Employee value proposition, Employer attractiveness, Startup

How to cite: Ariyanto, R., \& Kustini, K. (2021). Employer branding and employee value proposition: The key success of startup companies in attracting potential employee candidates. Annals of Human Resource Management Research, 1(2), 113-125.

\section{Introduction}

In the current era of globalization, many changes are challenging to predict. The changes that occur have an impact on all sectors of human life, including the business sector. One of the business sector models that are currently thriving is a startup. A startup is a new company that is pioneering its growth to survive (Dash, 2019).

At this time, the wave of competition in the startup world is increasing in Indonesia. According to Startupranking.Com(2021), Indonesia occupies the 5th position in the world with the largest number of startups, amounting to 2,225 startup companies. This shows that surviving and competing in the digital industry is not easy. Competent and talented human resources are needed in managing company resources to continue to survive and compete. According to Ardana, Mujiati, and Utama (2012), the success or failure of an organization is determined by the human resources in it. Human resources can be regarded as company assets whose benefits must be maintained.

When viewed from the fairly tight competition, the company is faced with new challenges to attract potential prospective employees to work in the company or commonly referred to as Employer 
Attractiveness. Employer attractiveness is a description or perception of a company by prospective employees if they want to work in the company (Buren, 2012). It can be a picture that can influence the decision of prospective employees to work in the company or vice versa. According to Saini, Rai, and Chaudhary (2014), a person's interest in choosing a company is influenced by the following seven things: Wages/salaries that prospective employees will receive, promotion opportunities, environmental policies, termination policies, company services or products, company location, and the reputation or image of the company's brand.

A strong brand is one of the factors that can create the interest of prospective employees to work in the company, which is commonly referred to as employer branding. According to Miles and Mangold (2004), employer branding is an assumption about a brand created by a company to improve its reputation to motivate prospective employees to internalize the brand to themselves. With a good brand from the company, it is expected to create interest in prospective employees to join the company.

In addition to employer branding, a supporting strategy from the company is also needed to show the values obtained when the employees work at the company, namely the Employee Value Proposition. According to Review and Backhaus (2016), Employee Value Proposition is reciprocity that prospective employees will obtain for their performance. It can include special abilities and experience brought to the company. It is because non-financial value or reciprocity can affect a person's work both in terms of job satisfaction or satisfaction with a company (Okello Ochwo, B et al., 2021)

Startup Campuspedia Indonesia is one of the digital technology-based companies in education, which was pioneered in 2016 in the city of Surabaya, Indonesia. This startup is a company that focuses on developing the world of education and skills training for students and fresh graduates who want to continue working in the industrial world.

One of the ways for the Startup Campuspedia Indonesia to acquire competent employees is through the internship program. The internship program is an activity to share knowledge and experience that has been gained from school or college in the world of work (Nugraheni and Wijaya, 2017). In addition, according to Hardie, Almeida, and Ross (2018), the internship program can have a positive impact because it can develop knowledge that is more relevant to a job. The selection of internship participants as prospective employees is because they have already gone through the stages of the recruitment process, which is quite long until they are declared to have passed as internship participants. In addition, there is already a track record of working for three months during the internship period, so that it is considered more convincing of the potential possessed by the prospective employee. However, from the company data, the number of the likelihood of prospective employees (internship participants) interested in continuing to work at the company has decreased. This can be seen from Table 1.1 below:

Table 1. Number of 2020 internship participants continuing to work in Startup Campuspedia Indonesia

\begin{tabular}{|l|l|l|l|}
\hline Batch & $\begin{array}{l}\text { Number of Potential } \\
\text { Employee Candidates }\end{array}$ & $\begin{array}{l}\text { Number of Employees Who are } \\
\text { Interested in Working in the Company }\end{array}$ & $\begin{array}{l}\text { Percentage } \\
(\%)\end{array}$ \\
\hline Batch 7 & 23 Participants & 1 & $0.23 \%$ \\
\hline Batch 8 & 22 Participants & 2 & $0.44 \%$ \\
\hline Batch 9 & 61 Participants & 2 & $1.22 \%$ \\
\hline
\end{tabular}

Source: Campuspedia Indonesia (2021)

Based on table 1, it can be seen that the number of internship participants who are interested in continuing to work at the company tends to be small. In batch 7 , out of the 23 potential employee candidates, only one person is interested in working in the company or with a percentage of $0.23 \%$, in batch 8 , out of the 22 potential employee candidates, only two people are interested or with a 
percentage of $0.44 \%$, and in batch 9 , out of the 61 potential employees, only two people are interested in working in the company or with a percentage of $1.22 \%$. This identifies that potential employees are not interested in continuing to work in Startup Campuspedia Indonesia, even though from the company side, it has provided broad opportunities for potential employees to continue working at the company as an agent for developing company products, such as TOEFL Tryout, UTBK Tryout, Online Career Class (OCC), and other company products. From the results of interviews with several internship participants in batches 7,8 , and 9 , an indication can be drawn that several things cause them to be less interested in continuing to work in the company, namely in terms of applying the brand built by the company and the value provided by the company that is not in line with expectations. So, they cause a lack of interest in potential employees to work in the company. Therefore, from the description above, this study aims to examine the influence of employer branding and employee value proposition on employer attractiveness at Startup Campuspedia Indonesia.

\section{Literature review}

\subsection{Employer branding}

Employer Branding is a strategy developed and implemented by a company to show the superiority of the company's brand, so that prospective employees can see it. It can be in job descriptions, economic benefits, or psychological benefits for a particular position. According to Ambler and Barrow (1996), Employer Branding is a company brand marketing technique in finding the best candidates to attract new employees and retain old employees. Miles and Mangold (2004) defined employer branding as an approach to brands created by companies to improve reputation to motivate prospective employees to internalize the brands to themselves. And according to Dudley (2019), employer branding can effectively communicate a unique and positive company as an aspect of increasing the company's attractiveness in the labor market, especially skilled potential employees. According to Martin, Gollan, and Grigg (2011), employer branding can significantly contribute to innovation and transformation of changes in a company's business model through its capital and social image.

Five benchmarks can be used to measure employer branding according to Berthon, Ewing, and Hah, 2005. Those five benchmarks are: (1) Interest Value, which is about assessing a person's interest in a company in terms of a positive work environment, companies that have superior products or services, and attractive job offers, (2) Social Value, which is about assessing the extent to which a company can provide harmonious family relationships, a mutually supportive team, and a comfortable work environment as a place to work, (3) Economic Value, which is about assessing a company that can provide promising economic benefits, either in the form of salary or other compensation, as well as job security and opportunities to get a more decent position, (4) Development Value, which is about assessing a company that can provide a place to build self-ability, quality and confidence, and career development to support its future performance, (5) and Application Value, which is about assessing a company that can provide science in a work environment that aims for customers and humanity.

\subsection{Employee value proposition}

Employee Value Proposition (EVP) is a balance of awarding the results of the performance that has been done to a company. According to Review and Backhaus (2016), EVP is reciprocity that prospective employees will obtain for the work that has been done to a company. This can include special abilities and experience brought by the prospective employees to the company. In developing an employee value proposition strategy, it is necessary to consider the capabilities of the company and the wishes or expectations of prospective employees to attract and retain employees. According to Sengupta, Bamel, and Singh (2015), potential employees will be able to stay in the company when applying employee value propositions can be implemented by proper planning.

Five benchmarks can be used to measure the employee value proposition according to Parreira and Honours (2007). Those five benchmarks are: (1) Reward, which is giving an award for the achievements that an employee has made for the company, and it can be in the form of salary, insurance, company car, or other compensation, (2) Opportunity, which is an opportunity offered by a company after prospective employees join the company, and these opportunities can be in the form of available positions or other opportunities, (3) Organization, which is the type and culture of the company or industry that prospective employees want to work for, (4) Work, which is the type of 
work that will be done by prospective employees when they join the company, and this can be in the form of conformity with the wishes of the employees or not, (5) People, who are employees in the company, and this can be in the form of harmonious, mutually supportive relationships between employees, or vice versa, which can reflect the company's culture.

\subsection{Employer attractiveness}

According to Buren (2012), Employer Attractiveness is a description or assumption of a company by prospective employees if they want to work in the company. According to Sokro (2012), this interest can come from the description of the level of security at work, improving self-quality, and working conditions that can provide competitive advantages in the form of compensation, learning opportunities, or positions in the future.

Six benchmarks can be used to assess the Employer Attractiveness of a company (Parreira and Honours, 2007). Those six benchmarks are: (1) Emotional Appeal interests that can influence prospective employees through emotional attraction, such as feeling happy about the company, feeling proud, and feeling safe or trusting in the company, (2) Products and Services interests that are influenced by the products owned by the company and or the services provided by the company, (3) Vision and Leadership interests that are influenced by the company's goals, goals that are focused on market trends, and a good leadership that can protect, (4) Workplace Environment interests that are influenced by a good work environment, a quality company management system, and employees who have superior and supportive abilities, (5) Social and Environmental Responsibility interests that are influenced by reasonable corporate social goals which can resolve community conflicts and have a responsibility to nature, and (6) Financial Performance interests that are influenced by the company's financial growth conditions which have good growth prospects in the future.

\subsection{Previous empirical studies}

\subsubsection{Relationship between employer branding and employer attractiveness}

Based on the opinions of several experts and previous researches, there is a relationship between employer branding and employer attractiveness. According to Bodderas et al. (2011), Employer Branding affects the interest of prospective employees in choosing a job. In addition, according to Yudianto (2020), Employer Branding has a significant effect on employer attractiveness. Based on this, it can be concluded that employer branding can increase the appeal of prospective employees to work in the industry. The better employer branding applied by an enterprise will increase the interest of prospective employees to work in that industry.

Hypothesis 1 (H1). Employer branding (X1) affects Employer Attractiveness (Y) at Startup Campuspedia Indonesia.

\subsubsection{Relationship between employee value proposition and employer attractiveness}

According to several experts and previous researches, there is a significant influence between the employee value proposition and employer attractiveness. According to Yudianto (2020), Employee Value Proposition benchmarks can affect the interest of prospective employees in choosing a company. According to Yuenardy (2018), the employee value proposition affects the employer attractiveness of job seekers in choosing a job. Primastuti (2014) reinforced this opinion, saying that the interest of prospective employees was influenced by the employee value proposition variable, which referred to an industry that was innovative and had a quality work culture, as well as the process of finding the right candidate. So, it can be concluded that using the right employee value proposition strategy can increase the interest of potential employees to work in the company.

Hypothesis 2 (H2). Employee value proposition (X2) affects Employer Attractiveness (Y) at Startup Campuspedia Indonesia.

\subsection{Conceptual framework}

Initially, the framework of thought comes from several theories and designs suitable for the case being studied. In general, a reasonable frame of mind will explain the link between variables in the 
study theoretically. According to Sugiyono (2010), the framework of thinking can produce a reasonable hypothesis when a researcher can master scientific theory in his/her research. The framework of thinking can be interpreted as a brief explanation of the phenomenon being studied. Other than that, the framework of thinking results from identifying a problem that can lead to a relationship between theory and various variables that can produce a conceptual model that fits the case. Then, the variables used in the case of Startup Campuspedia Indonesia are Employer Branding (X1), Employee Value Proposition (X2), and Employer Attractiveness (Y). So, this research framework can be described as follows:

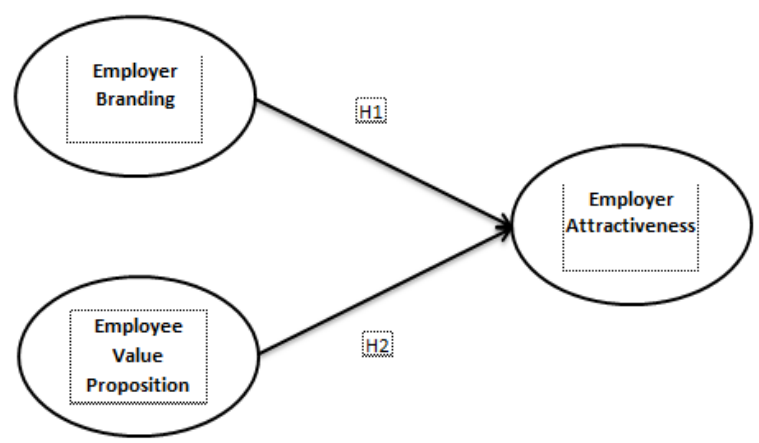

Figure 1. Conceptual framework

\section{Research methodology}

\subsection{Variable measurement}

The weighting of the variables used in this research is the Likert scale. According to Sugiyono (2013), the Likert scale is a proportion that can measure a phenomenon based on the behavior, opinions, and descriptions of individuals or groups. This scale is used because it is easy to make, free of staterelated statements, has a high degree of relevance, and can be applied to various data processing software. When using a Likert scale, the variables to be assessed are presented as the benchmark variables. Then, the benchmark is used as a starting point for compiling instrument items that can be in the form of statements. This research uses a statement with a scale of 5.

The benchmark above is assessed on a Likert scale which has five levels of response options, each of which has a score of 1-5 as follows:

$\begin{array}{ll}\text { Strongly Agree (SS) } & =\text { rated with a weight of } 5 \\ \text { Agree (S) } & =\text { rated with a weight of } 4 \\ \text { Moderately Agree (CS) } & =\text { rated with a weight of } 3 \\ \text { Disagree (TS) } & =\text { rated with a weight of } 2 \\ \text { Strongly Disagree (STS) } & =\text { rated with a weight of } 1\end{array}$

In this study, respondents are required to choose one of the five categories of answers that have been provided, and then each answer will be given a specific score. Respondent scores will be added up and become the total score, and this total score will be interpreted as the respondent's position on the Likert scale.

\subsection{Types of research}

This study adopts a case study design using a quantitative approach. This study uses primary data derived from the results of questionnaires that have been filled out by respondents.

\subsection{Population}

The population used in this study was 106 potential employee candidates for Startup Campuspedia Indonesia batches 7, 8, and 9. According to Sugiyono (2015), population comprises subjects and objects that have the same number and character. 


\subsection{Sample}

According to Sugiyono (2015), sample is a part of the number of the population that can represent the entire population. The sampling uses the Slovin formula in Sugiyono (2013) with precession taken as much as $10 \%$ to maintain a representation of the research sample:

Information:

$$
n=\frac{N}{N(e)^{2}+1}
$$

N: Total of Population

E: Margin of error (10\%)

Result of Calculation:

$\mathrm{n}=106 /(1+(106 \times 0.12))$

$=106 / 2.06$

$=51.4$ (rounded down to 51 respondents)

\subsection{Sampling technique}

The samples in this study were 51 respondents using the proportional random sampling technique. According to Sugiyono (2013), proportional random sampling is a random way of taking samples while still paying attention to the strata of the population used. Then, the number of samples will be calculated according to the following formula:

$$
N=\frac{n}{S} \times n
$$

Information:

$\mathrm{N}$ : sample quantity batch

$\mathrm{n}$ : population quantity batch

S: Total population in all batches

The results of the calculation of proportional random sampling are obtained as follows:

- Batch $7=23 / 106 \times 51=11$ Samples

- Batch $8=22 / 106 \times 51=11$ Samples

- Batch $9=61 / 106 \times 51=29$ Samples

Total $=51$ samples

\subsection{Analysis techniques and hypothesis testing}

The investigative technique applied in this research is Partial Least Square (Smart PLS), a technique for combining predictable shapes when a large number of components are used. PLS is also a component of the indeterminacy of a solid analytical technique because it does not presuppose information to be assessed on a specific scale and a small sample quantity.

For prediction targets, the PLS approach is more suitable because this approach estimates the latent variables, which are considered linear mixtures of the benchmarks to avoid indeterminacy problems and describe the exact results of the value part.

\section{Results and discussions}

\subsection{Analysis of respondents' characteristics}

Respondents in this research were the potential employees of Startup Campuspedia Indonesia with a total of 51 respondents distributed from June 18, 2021 via WhatsApp Blast. The results obtained were the characteristics of respondents based on gender and Internship Period. The following are the results of each respondent's characteristics: 


\subsubsection{Gender}

Characteristics of respondents based on gender can be seen in Table 4.1 below:

Table 2. Characteristics of respondents based on gender

\begin{tabular}{|c|l|c|c|}
\hline Number & \multicolumn{1}{|c|}{ Gender } & Respondent Quantity & Percentage (\%) \\
\hline 1 & Man & 20 & 39.2 \\
\hline 2 & Woman & 31 & 60.8 \\
\hline \multicolumn{2}{|c|}{ Total } & $\mathbf{5 1}$ & $\mathbf{1 0 0}$ \\
\hline
\end{tabular}

Source: Data Processing Result (2021)

Table 2 shows that the characteristics of respondents who become potential employees of Startup Campuspedia Indonesia are seen from the percentage of gender. Most of the respondents are female prospective employees that reach $60.8 \%$ of the entire sample population and the remaining $39.2 \%$ are male. This is because the female gender dominates the results of the Campuspedia internship recruitment process.

\subsubsection{Internship period}

Characteristics of respondents based on the internship period can be seen in Table 4.2 below:

Table 3. Characteristics of respondents based on internship period

\begin{tabular}{|c|l|c|c|}
\hline Number & Internship period & Respondent Quantity & Percentage (\%) \\
\hline 1 & Batch 7 & 11 & 21.6 \\
\hline 2 & Batch 8 & 11 & 21.6 \\
\hline 3 & Batch 9 & 29 & 56.8 \\
\hline \multicolumn{2}{|c|}{ Total } & $\mathbf{5 1}$ & $\mathbf{1 0 0}$ \\
\hline
\end{tabular}

Table 3 above shows that the number of respondents is proportional or based on the number of sample needs. In batch 7 and batch 8 , the number of respondents each amounted to 11 or with a percentage of $21.6 \%$. Then, in batch 9 , the number of respondents was 29 or with a percentage of $56.8 \%$.

\subsection{Description of research results}

Responses from respondents about the effect of Employer Branding (X1) and Employee Value Proposition (X2) on Employer Attractiveness (Y1) to 51 respondents of potential employees of Startup Campuspedia Indonesia in the answers were stated using a range of 1 to 5 on each scale, where a value of 1 indicates the lowest value and a value of 5 indicates the highest value.

The following is a description of each variable used in this study:

4.2.1. Employer branding

Table 4. Descriptive statistics of employer branding

\begin{tabular}{|c|l|c|c|}
\hline \multirow{2}{*}{ Indicators } & \multicolumn{1}{|c|}{ Statement } & \multicolumn{2}{c|}{ Descriptive Statistics } \\
\cline { 3 - 4 } & & Mean & Std. deviation \\
\hline X1.1 & $\begin{array}{l}\text { The company has a good working environment and a } \\
\text { supportive team atmosphere }\end{array}$ & 3.62 & 999 \\
\hline X1.2 & $\begin{array}{l}\text { The company provides broad opportunities to learn } \\
\text { sciences in the company without restrictions }\end{array}$ & 4.05 & 881 \\
\hline X1.3 & $\begin{array}{l}\text { The company has good learning quality and provides } \\
\text { additional knowledge through upgrading }\end{array}$ & 3.74 & 890 \\
\hline \multicolumn{2}{|c|}{ Average } & $\mathbf{3 . 7 9}$ & $\mathbf{9 2 3}$ \\
\hline
\end{tabular}

From table 4 above, it can be seen that the mean for employer branding is 3.79 , which means agree or good. This shows that the respondents agree if the employer branding implemented by the company is appropriate. The highest mean is obtained from the statement X1.2 that the company provides broad opportunities to learn sciences in the company without restrictions with a mean of 4.05 , which means that respondents agree on the value of individual development in the form of upgrading or developing other skills that are useful in supporting the given employee's performance by the company. 
4.2.2. Employee value proposition

Table 5. Descriptive statistics of employee value proposition

\begin{tabular}{|c|l|c|c|}
\hline \multirow{2}{*}{ Indicators } & \multicolumn{1}{|c|}{ Statement } & \multicolumn{2}{|c|}{ Descriptive Statistics } \\
\cline { 3 - 4 } & \multicolumn{1}{|c|}{ Mean } & Std. deviation \\
\hline X2.1 & $\begin{array}{l}\text { The company provides compensation for the work I } \\
\text { have done }\end{array}$ & 2.90 & 1.153 \\
\hline X2.2 & $\begin{array}{l}\text { The company provides development opportunities and } \\
\text { career paths }\end{array}$ & 3.60 & 1.001 \\
\hline X2.3 & The company gives me the job I want & 3.47 & 1.101 \\
\hline \multicolumn{1}{|c|}{ Average } & 3.32 & 1.085 \\
\hline
\end{tabular}

From table 5 above, it can be seen that the mean for the Employee Value Proposition is 3.32, which means moderately agree. This shows that the respondents moderately agree if the employee value proposition implemented by the company is quite appropriate. The highest mean is obtained from the statement X2.2 that the company provides development opportunities and career paths with a mean of 3.60 , which means that respondents agree with the opportunities offered by companies, such as opportunities to develop and have career paths at Startup Campuspedia Indonesia.

\subsubsection{Employer attractiveness}

Table 6. Descriptive statistics of employer attractiveness

\begin{tabular}{|c|l|c|c|}
\hline \multirow{2}{*}{ Indicators } & \multicolumn{1}{|c|}{ Statement } & \multicolumn{2}{c|}{ Descriptive Statistics } \\
\cline { 3 - 4 } & & Mean & Std. deviation \\
\hline Y1.1 & The company has high-quality products and services & 3.84 & 809 \\
\hline Y1.2 & The company has good goals and leadership & 3.90 & 830 \\
\hline Y1.3 & $\begin{array}{l}\text { The company has a good culture and management } \\
\text { system }\end{array}$ & 3.13 & 1.216 \\
\hline \multicolumn{2}{|c|}{ Average } & $\mathbf{3 . 6 2}$ & $\mathbf{9 5 , 1}$ \\
\hline
\end{tabular}

From table 6 above, we can see that the mean for Employer Attractiveness is 3.62, which means agree or good. This shows that the Employer Attractiveness implemented by the company is appropriate. The highest mean is obtained from the statement Y1.2 that the company has good goals and leadership with a mean of 3.90, which means that one of the biggest interests of potential employees is through the company's vision and mission as an educational company and leadership carried out by superiors who are quite good.

\subsection{Interpretation of $P L S$ data processing results}

4.3.1. PLS Model analysis

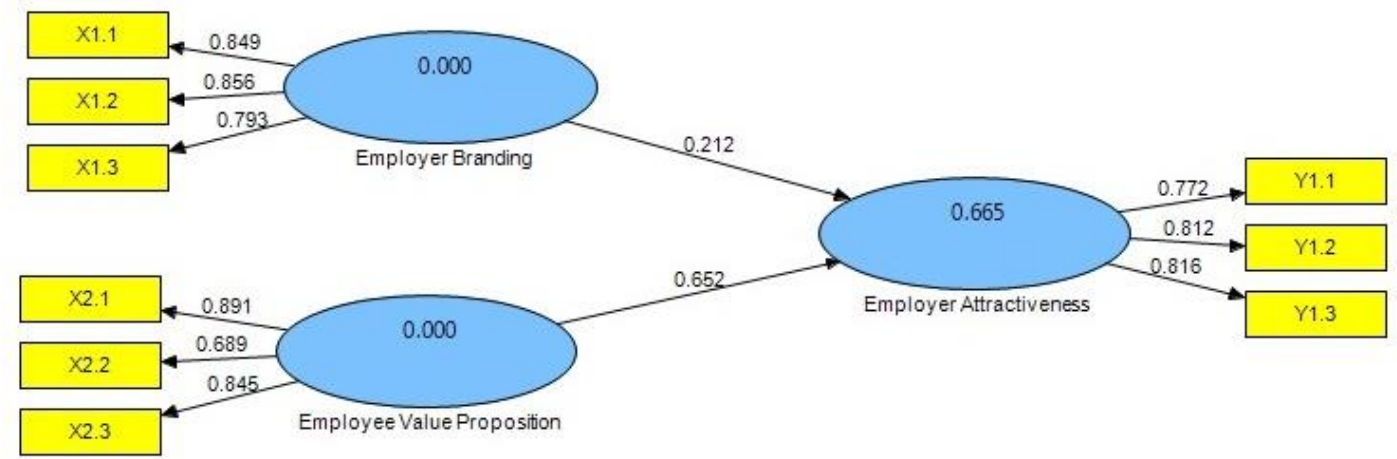

Figure 2. Conceptuality with Factor Loading, Path Coefficient, and R-Square

We can see the magnitude of the factor loading value in the indicator parts above the arrow between one variable and another benchmark. It also describes the importance of the coefficient that is right above the arrow line in each direction of the employer branding variable (X1) to employer 
attractiveness (Y) and employee value proposition (X2) to employer attractiveness (Y). In addition, we can also see the amount of R-square, which is in the roundabout of the endogenous variable, namely employer attractiveness.

\subsubsection{Outer model (Measurement model and indicator validity)}

The outer loading output table is used in this model because all indicators use reflective indicators, namely employer branding (X1) and Employee value proposition (X2), and use endogenous employer attractiveness $(\mathrm{Y})$ variable. The following is the outer loading table resulting from the processing.

Table 7. Outer loadings (Mean, STEDV, T-Values)

\begin{tabular}{|c|c|c|c|c|c|}
\hline & $\begin{array}{c}\text { Factor } \\
\text { Loading } \\
(\mathbf{O})\end{array}$ & $\begin{array}{c}\text { Sample } \\
\text { Mean } \\
(\mathbf{M})\end{array}$ & $\begin{array}{c}\text { Standard } \\
\text { Deviation } \\
(\text { STDEV) }\end{array}$ & $\begin{array}{c}\text { Standard } \\
\text { Error } \\
(\mathbf{S T E R R})\end{array}$ & $\begin{array}{c}\text { T Statistics } \\
(\mid \mathbf{O} / \mathbf{S T E R R})\end{array}$ \\
\hline $\mathrm{X} 1.1$ <- Employer Branding & 0.848814 & 0.851468 & 0.019819 & 0.019819 & 42.827487 \\
\hline $\mathrm{X} 1.2<-$ Employer Branding & 0.855677 & 0.855196 & 0.019069 & 0.019069 & 44.873557 \\
\hline $\mathrm{X} 1.3$ <- Employer Branding & 0.792690 & 0.791379 & 0.027317 & 0.027317 & 29.018584 \\
\hline $\mathrm{X} 2.1$ <- Employee Value Proposition & 0.890742 & 0.889314 & 0.017921 & 0.017921 & 49.703753 \\
\hline $\mathrm{X} 2.2$ <- Employee Value Proposition & 0.688812 & 0.690217 & 0.045336 & 0.045336 & 15.193376 \\
\hline $\mathrm{X} 2.3$ <- Employee Value Proposition & 0.844656 & 0.845118 & 0.024142 & 0.024142 & 34.986827 \\
\hline Y1.1 <- Employer Attractiveness & 0.771916 & 0.774783 & 0.032489 & 0.032489 & 23.759013 \\
\hline Y1.2 <- Employer Attractiveness & 0.812467 & 0.811957 & 0.022572 & 0.022572 & 35.994490 \\
\hline Y1.3 <- Employer Attractiveness & 0.815958 & 0.817338 & 0.025816 & 0.025816 & 31.606346 \\
\hline
\end{tabular}

Factor loading is a line relationship that occurs between indicators and variables. From table 7 above, it can be said that the validity is sufficient when it is more significant than 0.5 and/or the T-Statistic value is greater than $1.96(\mathrm{Z}$ value $=0.05)$. Data processing results that have been carried out can be said to be valid if the validity is more significant than 0.5 (fulfilled) and the T-Statistics is more significant than 1.96 (significantly fulfilled).

If seen from table 7, the results of all reflective indicators on the Employer Branding, Employee Value Proposition variables, and Employer Attractiveness, show that they are appropriate and fulfilled, so that it can be said that the validity is good. It is because the loading factor (original sample) shows results greater than 0.50 and/or significant ( $\mathrm{T}$-Statistic value is higher than $\mathrm{Z}$ value $=$ $0.05(5 \%)=1.96)$.

In addition to the methods described above, we can also see whether data can have good benchmark validity or not, namely through a cross-loading table, which is by looking directly if the loading factor value of each benchmark in each variable is > loading factor for each benchmark measure on other variables, then the loading factor is said to be valid. However, if the value of the loading factor is < the benchmark of the other variables, then it can be said to be invalid.

Table 8. Cross loading

\begin{tabular}{|c|c|c|c|}
\hline & Employee Value Proposition & Employer Attractiveness & Employer Branding \\
\hline $\mathrm{X} 1.1$ & 0.642032 & 0.617466 & 0.848814 \\
\hline $\mathrm{X} 1.2$ & 0.645922 & 0.541938 & 0.855677 \\
\hline $\mathrm{X} 1.3$ & 0.458887 & 0.508720 & 0.792690 \\
\hline $\mathrm{X} 2.1$ & 0.890742 & 0.712754 & 0.679503 \\
\hline
\end{tabular}




\begin{tabular}{|c|l|l|l|}
\hline $\mathrm{X} 2.2$ & 0.688812 & 0.543845 & 0.550609 \\
\hline $\mathrm{X} 2.3$ & 0.844656 & 0.684425 & 0.488851 \\
\hline $\mathrm{Y} 1.1$ & 0.566954 & 0.771916 & 0.349180 \\
\hline $\mathrm{Y} 1.2$ & 0.710816 & 0.812467 & 0.544825 \\
\hline $\mathrm{Y} 1.3$ & 0.632911 & 0.815958 & 0.682757 \\
\hline
\end{tabular}

From the results of cross loading data on the Employer Branding, Employee Value Proposition, and Employer Attractiveness variables, each benchmark has a good value, and this illustrates that all of the models in this research can be fulfilled for validity or it can be said that the validity is good because it has a high factor loading value more significant than the loading of the benchmark factors of the other variables.

Table 9. Average variance extracted, composite reliability, and R-Square

\begin{tabular}{|c|c|c|c|}
\hline & AVE & $\begin{array}{c}\text { Composite } \\
\text { Reliability }\end{array}$ & R-Square \\
\hline Employer Branding & 0.693675 & 0.871560 & \\
\hline Employee Value Proposition & 0.660443 & 0.852269 & \\
\hline Employer Attractiveness & 0.640582 & 0.842358 & 0.664785 \\
\hline
\end{tabular}

The AVE test results for the Employer Branding variable, the Employee Value Proposition variable, and the Employer Attractiveness are 0.693675, 0.660443, and 0.640582, respectively. The three variables show a value of more than 0.5 , so that in overall, the variables in this study can be valid.

Composite reliability can be said to be consistent in measuring latent variables when it shows a number of above 0.70 in the measurement of reliable constructs.

The results of the Composite Reliability test show that the Employer Branding variable is 0.871560 , the Employee Value Proposition variable is 0.852269, and the Employer Attractiveness is 0.842358 . The three variables can be said to be reliable because they have numbers of above 0.70 .

$\mathrm{R}^{2}$ value $=0.664785$. It can be interpreted that the model can explain the phenomenon of Employer Attractiveness influenced by independent variables, including Employer Branding and Employee Value Proposition variance of $66.47 \%$. Meanwhile, the remaining $33.53 \%$ is explained by other variables outside this research (besides Employer Branding and Employee Value Proposition). Furthermore, the path coefficients in the inner model can be seen in the hypothesis testing with inner weights.

\subsubsection{Correlation test}

Table 10. Correlation test

\begin{tabular}{|c|c|c|c|}
\hline & $\begin{array}{c}\text { Employee Value } \\
\text { Proposition }\end{array}$ & $\begin{array}{c}\text { Employer } \\
\text { Attractiveness }\end{array}$ & $\begin{array}{c}\text { Employer } \\
\text { Branding }\end{array}$ \\
\hline Employee Value Proposition & 1.000000 & & \\
\hline Employer Attractiveness & 0.801354 & 1.000000 & \\
\hline Employer Branding & 0.704429 & 0.671239 & 1.000000 \\
\hline
\end{tabular}

The table of latent variable correlations above shows a relationship between one variable or construct and another construct, be it endogenous and exogenous variables or exogenous and exogenous variables. The relationship between one variable and another can be good when it gets closer to 1 because the maximum value of the correlation is 1 . 
From the table of latent variable correlations, the mean value of the relationship between one variable and another shows the mean value of the relationship of above 0.5. The highest number of connections is found in the Employee Value Proposition variable with Employer Attractiveness, which is 0.801354. This illustrates that the relationship between the Employee Value Proposition variable and Employer Attractiveness describes a more substantial relationship than the relationship between other variables among the variables in this type of research. It can also be concluded that in this type of research, the level of Employer Attractiveness is more influenced by the Employee Value Proposition variable than the Employer Branding variable.

Tabel 11. Path coefficients (Mean, STDEV, T-Values)

\begin{tabular}{|c|c|c|c|c|c|}
\hline & $\begin{array}{c}\text { Path } \\
\text { Coefficients } \\
(\mathbf{O})\end{array}$ & $\begin{array}{c}\text { Sample } \\
\text { Mean (M) }\end{array}$ & $\begin{array}{c}\text { Standard } \\
\text { Deviation } \\
(\text { STDEV) }\end{array}$ & $\begin{array}{c}\text { Standard } \\
\text { Error } \\
(\text { STERR) }\end{array}$ & $\begin{array}{c}\text { T Statistics } \\
(\mid \mathbf{O} / \text { STERR|) }\end{array}$ \\
\hline $\begin{array}{c}\text { Employer Branding (X1) -> } \\
\text { Employer Attractiveness (Y) }\end{array}$ & 0.211881 & 0.212202 & 0.067832 & 0.067832 & 3.123639 \\
\hline $\begin{array}{c}\text { Employee Value Proposition } \\
\text { (X1) -> Employer } \\
\text { Attractiveness (Y) }\end{array}$ & 0.652099 & 0.653997 & 0.058213 & 0.058213 & 11.202026 \\
\hline
\end{tabular}

a. Employer Branding (X1) has a positive effect on Employer Attractiveness (Y), which is acceptable, with a path coefficient value of 0.211881 and a T-statistic value of 3.123639, which is greater than the value of $Z=0.05(5 \%)=1.96$, so that it is Significant (Positive).

b. Employee Value Proposition (X2) has a positive effect on Employer Attractiveness (Y), which is acceptable, with a path coefficient value of 0.652009 and a T-statistic value of 11.202026, which is greater than the value of $Z=0.05(5 \%)=1.96$, so that it is Significant (Positive).

\subsection{Discussion of research results}

4.4.1. Employer branding has a positive effect on employer attractiveness

Based on the testing that has been carried out, the results show that Employer Branding (X1) has a positive effect on Employer Attractiveness (Y) with a path coefficient value of 0.211881 and a Tstatistic value of 3.123639, which is greater than the value of $Z=0.05(5 \%)=1.96$. This means that good employer branding can increase the interest of potential employees to work for the company. It follows a research by Chhabra and Sharma (2014) which stated that solid employer branding could increase a person's interest in choosing a company as a place to work. The increasing interest of potential employees in a company will make it easier for human capital to get the best candidates in the recruitment process.

The results of this test show that employer branding carried out by companies is quite effective in influencing the interest of potential employees to work at Startup Campuspedia Indonesia. The indicator of the employer branding variable, namely social value, has the most significant factor loading of 0.848. It can be concluded that this indicator is the strongest in shaping the employer branding variable and affects employer attractiveness. This shows that Startup Campuspedia Indonesia has a good work environment and a supportive team atmosphere, such as having a positive work environment, having the opportunity to develop each other up, and having a supportive team to create employer attractiveness for potential employees of Startup Campuspedia Indonesia. This is also in line with a research by Badi'ah, Swasti, and Ariyanto (2021), which stated that the development process carried out by Startup Campuspedia Indonesia was quite good, especially in developing talent management as well as skills development through upgrading, which was held every month, so that it could also create the interest of potential prospective employees to work in the company. In addition, according to Pawar and Charak (2015), good Employer Branding is the principal capital of a company in retaining old employees and getting potential employees. This follows the opinion of Rumangkit 
and Dwiyan (2019), which stated that employer branding indicators strongly influenced job seekers in choosing a company to work for.

\subsubsection{Employee Value Proposition Positively affects Employer Attractiveness}

Based on the results of the tests that have been carried out, the results show that the Employee Value Proposition has a positive effect on Employer Attractiveness with a path coefficient value of 0.652009 and a T-statistic value of 11.202026, which is greater than the value of $Z=0.05(5 \%)=1.96$. This means that it follows the research results of Yuenardy (2018), which stated that a reasonable employer value proposition cosuld increase the interest of prospective employees to work in the company.

The results of this test show that the indicator of the employee value proposition, namely rewards, has the most significant loading factor, which is 0.890 . This means that this indicator is the strongest in forming the employee value proposition. Following the conditions at Startup Campuspedia Indonesia, potential employees will be interested in working for the company when they get the reward that suits them. Previous potential employees have also received rewards from the company when carrying out the internship process in fees and merchandises. In addition, other values that they will get are a positive work environment, an excellent corporate organizational culture, and an extensive network. According to Firdausy (2017), the indicators that exist in the employee value proposition, namely rewards, opportunity, organizations, work, and people, each affect a person's attractiveness in choosing a company to work for. According to Badi'ah, Swasti, and Ariyanto (2021), Startup Campuspedia Indonesia also applies talent management as one of the attributes of the company's attractiveness. That is by placing potential employees in their preferred field/passion, so that they will be comfortable with their work in the hope of working optimally and being loyal to the company. In addition, the company also provides indirect feedback through upgrading, rewards, and promotions for prospective employees who excel, This is done to be able to compete with other companies. According to Veldsman and Pauw (2018), potential employees can choose wisely where they will work because of the potentials they have, and this is a challenge for an organization. So, it is important to retain these employees.

\section{Conclusion}

Based on the results of testing the effect of Employer Branding and Employee Value Proposition on Employer Attractiveness at Startup Campuspedia Indonesia, it can be concluded that Employer Branding (X1) has a positive effect on Employer Attractiveness (Y) and Employee Value Proposition (X2) also has a positive effect on Employer Attractiveness (Y) at the Startup Campuspedia Indonesia. This means that good Employer Branding and the use of the right Employee Value Proposition strategy can affect the level of interest of potential employees to work at Startup Campuspedia Indonesia.

\section{Limitation and study forward}

The limitation in this study is that it only uses one startup company in the field of education as the object of research and has not used several companies with different backgrounds. For further researches, they are expected to expand the object of research by using several startup companies in both the same field and different fields, as well as increasing the number of research samples, so that they are more representative.

\section{References}

Ambler, T., \& Barrow, S. (1996). The employer brand. Journal of Brand Management, 4(3), 185206. https://doi.org/10.1057/bm.1996.42

Ardana, I. K., Mujiati, N. I., \& Utama, I. (2012). Manajemen sumber daya manusia.

Badi'ah, R., Swasti, I. K., \& Ariyanto, R. (2021). Analisis Manajemen Talenta Pada Divisi Public Relation dan Partnership Program Internship Campuspedia Batch 9.0. Maker: Jurnal Manajemen, 7(1), 64-80.

Berthon, P., Ewing, M., \& Hah, L. L. (2005). Captivating company: Dimensions of attractiveness in employer branding. International Journal of Advertising, 24(2), 151-172. 
https://doi.org/10.1080/02650487.2005.11072912

Bodderas, M., Cachelin, J. L., Maas, P., \& Schlager, T. (2011). The influence of the employer brand on employee attitudes relevant for service branding: An empirical investigation. Journal of Services Marketing, 25(7), 497-508. https://doi.org/10.1108/08876041111173624

Buren, A. Van. (2012). Social Media A Communication Tool for Employer Attractiveness Criteria in the Employer Branding Concept: An Exploratory Study. 1-35.

Chhabra, N. L., \& Sharma, S. (2014). Employer branding: strategy for improving employer attractiveness. International Journal of Organizational Analysis.

Dash, S. B. (2019). Startup companies: Life cycle and challenges. International Journal of Psychosocial Rehabilitation, 23(6), 732-737. https://doi.org/10.37200/IJPR/V23I6/PR190836

Dudley, M. S. (2019). How can Lyse AS become a more attractive employer for their target audiences?

Firdausy, W. A. (n.d.). Perbandingan Efektivitas Employee Value Proposition Terhadap Employee Engagement Generasi X Dan Y Pada PT. XYZ.

Hardie, G., Almeida, S., \& Ross, P. J. (2018). Value of Industry Mentoring and Resource Commitment to the Success of an Undergraduate Internship Program: A Case Study from an Australian University. International Journal of Work-Integrated Learning, 19(2), 155-168.

Martin, G., Gollan, P. J., \& Grigg, K. (2011). Is there a bigger and better future for employer branding? Facing up to innovation, corporate reputations and wicked problems in SHRM. The International Journal of Human Resource Management, 22(17), 3618-3637.

Miles, S. J., \& Mangold, G. (2004). A conceptualization of the employee branding process. Journal of Relationship Marketing, 3(2-3), 65-87.

Nugraheni, D., \& Wijaya, L. S. (2017). Pelaksanaan Program Internship Dalam Upaya Meningkatkan Citra Lembaga Pendidikan (Studi Kasus: Fakultas Teknologi Informasi-Universitas Kristen Satya Wacana). Scriptura, 7(2), 47-56.

Okello Ochwo, B., \& Mwesigwa, D. (2021). Reward strategies and job satisfaction in private companies: a case of Uganda Breweries-Luzira. Annals of Human Resource Management Research, 1(1), 69-83. https://doi.org/10.35912/ahrmr.v1i1.406

Parreira, J., \& Honours, B. A. (2007). An Analysis of an Employee Value. November.

Pawar, A., \& Charak, K. S. (2015). Employee Value Proposition Leading To Employer Brand: the Indian Organizations Outlook. International Journal of Management Research and Review, 5(12),1195-1203.

Primastuti, L. E. (2014). Persepsi Mahasiswa Ideal untuk Bekerja berdasarkan Dimensi Employer Attractiveness (Studi Pada Mahasiswa Strata 1 Bidang Sosial dan Humaniora).

Review, B. M., \& Backhaus, K. (2016). Beacon Management Review 2012. Organization Management Journal, 13(4), 29-36. http://dx.doi.org/10.1080/15416518.2016.1245128\%0A

Rumangkit, S., \& Dwiyan, M. (2019). DAMPAK EMPLOYEE BRANDING PADA EFEKTIVITAS REKRUTMEN ( Case Study: Generasi Z Indonesia ). Jurnal Bisnis Darmajaya, 05(01), 1-12.

Saini, G. K., Rai, P., \& Chaudhary, M. K. (2014). What do best employer surveys reveal about employer branding and intention to apply? Journal of Brand Management, 21(2), 95-111.

Sengupta, A., Bamel, U., \& Singh, P. (2015). Value proposition framework: implications for employer branding. Decision, 42(3), 307-323.

Sokro, E. (2012). Impact of employer branding on employee attraction and retention. European Journal of Business and Management, 4(18), 164-173.

Startupranking.com. (2021). Startupranking.Com.

Sugiyono. (2013). Metode penelitian kuantitatif kualitatif dan $R \& D$. Alfabeta.

Sugiyono. (2015). Statistik nonparametris untuk penelitian. CV. Alvabeta.

Sugiyono, S. (2010). Metode penelitian kuantitatif dan kualitatif dan $R \& D$. Alfabeta Bandung.

Veldsman, D., \& Pauw, D. (2018). The relevance of the employee value proposition for retention in the VUCA world of work. In Psychology of Retention (pp. 75-89). Springer.

Yudianto, R. P. (2020). Pengaruh Employer Branding Dan Employee Value Proposition Terhadap Employer Attractiveness Pada Generasi Z Di Kota Bekasi .September, 81.

Yuenardy, A. (2018). The Influence Of Employee Value Propositions Toward Employee Attractiveness At PT. Aplikasi Karya Anak Bangsa Panel Of Examiners. 